\title{
Assessment of Greenhouse Gas Emissions in Soybean Cultivation Fertilized with Biochar from Various Utility Plants
}

\author{
Maciej Kuboń $\left.{ }^{1}{ }^{(}\right)$, Marcin Niemiec ${ }^{2}$, Agnieszka Klimek-Kopyra ${ }^{3, *}$, Maciej Gliniak ${ }^{4}{ }^{\circledR}$, Jakub Sikora ${ }^{4}$, \\ Urszula Sadowska ${ }^{5}$, Agnieszka Ewa Latawiec ${ }^{1,6,7,8}$, Rafał Kobyłecki ${ }^{9}$, Robert Zarzycki ${ }^{9}$, Andrzej Kacprzak ${ }^{9}$ \\ and Michał Wichliński ${ }^{9}$
}

Citation: Kuboń, M.; Niemiec, M.; Klimek-Kopyra, A.; Gliniak, M.; Sikora, J.; Sadowska, U.; Latawiec, A.E.; Kobyłecki, R.; Zarzycki, R.; Kacprzak, A.; et al. Assessment of Greenhouse Gas Emissions in Soybean Cultivation Fertilized with Biochar from Various Utility Plants. Agronomy 2021, 11, 2224. https:// doi.org/10.3390/agronomy11112224

Academic Editors: Guopeng Liang, Yuan Li and Andong Cai

Received: 15 October 2021

Accepted: 1 November 2021

Published: 3 November 2021

Publisher's Note: MDPI stays neutral with regard to jurisdictional claims in published maps and institutional affiliations.

Copyright: (c) 2021 by the authors. Licensee MDPI, Basel, Switzerland. This article is an open access article distributed under the terms and conditions of the Creative Commons Attribution (CC BY) license (https:// creativecommons.org/licenses/by/ $4.0 /)$.
1 Department of Production Engineering, Logistics and Applied Computer Science, Faculty of Production and Power Engineering, University of Agriculture in Krakow, Mickiewicza Av. 21, 30-120 Krakow, Poland; Maciej.Kubon@urk.edu.pl (M.K.); a.latawiec@iis-rio.org (A.E.L.)

2 Department of Agricultural and Environmental Chemistry, Faculty of Agriculture and Economy, University of Agriculture in Krakow, Mickiewicza Av. 21, 31-120 Krakow, Poland; Marcin.Niemiec@urk.krakow.pl

3 Department of Agroecology and Plant Production, Faculty of Agriculture and Economy, Mickiewicza Av. 21, 31-120 Krakow, Poland

4 Department of Bioprocess Engineering, Faculty of Production and Power Engineering, Power Engineering and Automation, University of Agriculture in Krakow, Balicka 116B, 30-149 Krakow, Poland; Maciej.Gliniak@urk.edu.pl (M.G.); Jakub.Sikora@urk.edu.pl (J.S.)

5 The Institute of Machinery Exploitation, Ergonomics and Production Processes, University of Agriculture in Krakow, Balicka 116B, 30-149 Krakow, Poland; Urszula.Sadowska@urk.edu.pl

6 Rio Conservation and Sustainability Science Centre, Department of Geography and the Environment, Pontifical Catholic University of Rio de Janeiro, R. Marquês de São Vicente, 225-Gávea, Rio de Janeiro 22451-000, Brazil

7 School of Environmental Sciences, University of East Anglia, Norwich Research Park, Norwich NR4 7TJ, UK 8 International Institute for Sustainability, R. Dona Castorina 124, Rio de Janeiro 22460-320, Brazil

9 Department of Advanced Energy Technologies, Częstochowa University of Technology, Dabrowskiego 69, 42-201 Częstochowa, Poland; rafal.kobylecki@pcz.pl (R.K.); robert.zarzycki@pcz.pl (R.Z.); Andrzej.kacprzak@pcz.pl (A.K.); michal.wichlinski@pcz.pl (M.W.)

* Correspondence: agnieszka.klimek@urk.edu.pl

Abstract: Organic matter is an indispensable element of soil. Its quantity and quality affect its properties, e.g., structure, buffering, sorption capacity, air-water relations, and thermal properties. The purpose of the research was to assess greenhouse gas (GHG) emissions in soybean cultivation, fertilized with biochar from various crops. Two experimental factors were included: the dose of biochar and the type of biochar used as per raw material used in its production. The adopted functional unit was 1 ton of soybeans. To reach the adopted goal, a strict field experiment was carried out. The total amount of GHG emitted by the cultivation was calculated according to the ISO 14040 and ISO 14044 standards. The system boundaries included: GHG emissions from fertilizers and seeds used, GHG emissions related to biochar production, emissions related to fossil fuel combustion, and emissions related to the decomposition of crop residues and soil organic matter and the decomposition of biochar. The results of the research indicate a significant potential of biochar to reduce GHG emissions in agricultural production. From the environmental and production perspective, the addition of biochar at $60 \mathrm{Mg} \mathrm{ha}{ }^{-1}$ is the most advantageous. A further increase in the addition of biochar was related to a decrease in plant yield and an increase in GHG emissions per functional unit of the product. The use of biochar in soybean cultivation resulted in a $25 \%$ reduction in GHG emissions compared to the object without the biochar addition. The amount of GHG emissions for soybeans ranged from 846.9 to $1260.1 \mathrm{~kg}$ of $\mathrm{CO}_{2} / \mathrm{Mg}$. The use of biochar from forest biomass resulted in a higher yield, $12 \%$ on average, compared to sunflower husk biochar. The introduction of biochar to soils can be an effective improvement in the economic and environmental efficiency of plant production, as it increases the use of nutrients by the plant and intensifies carbon sequestration in soils.

Keywords: greenhouse gas emission; soybean cultivation; biochar; fertilization 


\section{Introduction}

Organic matter is an indispensable element of soil. Its quantity and quality affect its properties, e.g., structure, buffering, sorption capacity, air-water relations, and thermal properties. The intensification of plant cultivation and the related increase in the number of agricultural treatments, as well as the use of mineral fertilizers and limited organic fertilization cause a constant decrease in organic matter in agricultural soils. Reduced organic matter is one of the most important causes, as well as effects of soil degradation [1,2]. Technologies used in modern agriculture lead to a permanent reduction in the amount of organic matter in the soil. The decrease in the amount of organic carbon in the soil is the result of the mineralization of the humus. Its further intensification is a consequence of the increased aeration of the soil caused by many tillages combined with the limited use of fertilizers containing organic carbon. Moreover, soil organic matter is a carbon reservoir in the biogeochemical cycle of this element $[3,4]$. Therefore, the carbon contained in the soil positively impacts the fertility of the soil and its yield potential, and on the other hand, it reduces the environmental impact of agriculture. Enriching the soil with organic matter is a strategic element of the sustainable development of agriculture and is in line with the principles of all primary production quality management systems: GLOBAL GAP, Integrated Production, or SAI Platform [5-7]. Carbon introduced to the soil with organic fertilizers undergoes mineralization and humification. The share of individual processes depends on the chemical form of carbon introduced into the ecosystem, as well as soil $\mathrm{pH}$, its particle size composition, its level of microbiological activity and the production technology [8,9]. The primary production stage is critical in terms of environmental impact. Eldor and Paul [10] and de Sousa Lima et al. [11] point out the significant impact of the carbon-to-nitrogen ratio on the course of the transformation of carbon compounds in the soil. External means of production containing carbon impact on the properties of soils and the development of microbiological biocenoses. The intensification of humification processes, which leads to permanent binding of organic carbon, could be the consequence of the development of certain species of microorganism [12,13]. The remedy could be the concept of transforming organic fertilizers to increase their potential for permanent carbon fixation in the soil. Wang et al. [14] point to the positive effect of biochar mixtures with zeolites, which intensifies the humification processes in the soil. Agegnehu et al. [4] report that the effects of fertilization increases when biochar is mixed with compost, compared to the use of biochar alone. A mixture of biochar with natural fertilizers yielded better effects of the permanent binding of organic carbon [15]. Similarly, Oliveira et al. [16] and Awasthi et al. [17] indicate a much higher efficiency of humification processes after the introduction of biochar compared to other organic carbon materials. The authors found the relevant $(40 \%)$ reduction in carbon dioxide emissions when using biochar mixtures and unprocessed natural fertilizers. A reduction in GHG emissions was observed with the addition of biochar to the composting process [17]. Where permanent sequestration is concerned, using mixtures of biochar and mineral additives based on mineralization processes that lead to the decomposition of organic compounds and the emission of carbon in the form of carbon dioxide to the atmosphere could be more suitable. From the point of view of permanent carbon sequestration, mineralization processes are not favorable. Mineralization under full aerobic conditions leads to the formation of simple mineral compounds $\left(\mathrm{CO}_{2}, \mathrm{SO}_{2}, \mathrm{H}_{2} \mathrm{O}, \mathrm{NO}\right.$, etc.). With a limited access to oxygen, it is a decaying process, which, when running in anaerobic conditions, leads to the rotting of organic matter. Increasing the amount of organic matter permanently bound in the soil depends on the rate and direction of transformations of carbon compounds introduced into the soil with organic fertilizers. As part of the rationalization of natural resource management, it is critical to manage the soil in such a way so as to reduce its carbon emissions or, in special cases, to pursue a policy of soil carbon management in such a way as to permanently increase its accumulation in the soil. The effect of such actions is the reduction of agricultural activity-related anthropopressure [18,19]. 
The role of agricultural sciences and production practice is to find methods of permanent binding of carbon introduced into the soil as organic fertilizers. Organic matter introduced with traditional fertilizers such as manure, slurry, or green manure in agricultural soils is primarily mineralized, which is pointless from the point of view of permanent carbon sequestration.

The introduction of organic carbon in the form of biochar is more beneficial in terms of improving soil fertility and in terms of permanent carbon binding in the soil [20,21]. Yuan et al. [22] report that the efficiency of biochar introduced into the soil depends on the level of decomposition of organic matter, which, in turn, depends on the type of raw material of biochar and the temperature of biochar production. Raya-Moreno et al. [23] point out that the efficiency of permanent carbon bonding depends on the raw material from which biochar is made. These authors observed the long-term binding effect of the organic carbon contained in the biochar within two years of incubation, with a much better effect observed in the case of wood biochar than in the case of manure biochar. The transformation of carbon compounds in the soil also depends on the mineral fraction of the material, as pointed out by $\mathrm{Xu}$ et al. [24] Melas et al. [25] proved that biochar added to soil had a statistically significant effect on intensification of humification in the incubation experiment. According to the above authors, increasing the content of phosphorus and other elements in biochar can increase the potential of soil humus formation, while limiting the oxidation processes [26]. Awad et al. [27] found that the addition of the mineral fraction to biochar in the form of oyster shells or polymer compounds significantly increased the potential of the material to reduce GHG emissions from agrocenoses. Apart from reducing carbon dioxide emissions as part of the impact on soil properties and microorganism colonies, the potential of this material for carbon dioxide chemisorption is also important, as it can also reduce the emission of this compound from the soil. Xu et al. [28] report that the sorption capacity of biochar in relation to carbon dioxide is as high as $34 \mathrm{mg} \mathrm{g}^{-1}$ of biochar, where the capacity depends on the content of metallic elements.

A very important aspect of the use of biochar on agricultural land is the improvement of soil fertility, which results in the improved use of nutrients. The use of biochar on intensively used land reduces the emission of nitrogen oxides, considered the most important agricultural GHG [29].

The organic carbon contained in soil is a component of organic matter (humus). Its amount is of key importance for soil fertility and GHG emissions [30,31]. The double benefit of the permanent binding of organic carbon to soil has led to numerous scientific studies, not only on methods of processing organic matter prior to application to the soil. The research included the application methods themselves and the impact of specific soil properties on humification processes, which are the most important from the point of view of permanent carbon binding in the soil. Numerous research cited in this study confirm that the introduction of carbon into the soil as a biochar improves permanent binding of this element compared to unprocessed biomass. The positive effect of biochar is related to the induction of humification processes, the reduction of nitrogen oxide emissions, and the chemical binding of carbon dioxide emitted by soil microorganisms and plant roots. Maucieri et al. [32] found that the addition of biochar to the soil reduced carbon dioxide emissions by $28 \%$ and nitrogen oxide emissions by $12 \%$ compared to the control. The authors estimate that the use of biochar can reduce the level of GHG emissions by approx. $10 \%$, in addition to permanent carbon fixation in soil. The presented research clearly demonstrates the potential of thermally processed biomass in the process of carbon sequestration. Numerous authors point out the possibility of increasing the sequestration potential of the element due to the valorization of biochar with additives containing phosphorus, calcium, or magnesium. Thermal conversion of biomass is related to the emission of various gases into the atmosphere. Therefore, when calculating the potential for permanent carbon binding, one should take into account GHG emissions in the biochar production phase, as pointed out by [33,34]. In light of the data published in the scientific literature, attention should be paid to the potential of using biochar in the sequestration 
of this element in the soil. Data in the literature clearly show that the use of organic matter subjected to pyrolysis affects the permanent bonding of this element in the form of persistent organic compounds. To accurately assess the environmental effects of the use of biochar, studies related to the permanent carbon bonding potential should be carried out using biochar made from a specific raw material. When designing a biochar-based products, the possibility of valorizing biochar with mineral additives should be taken into account to increase the efficiency of the product in terms of permanent carbon bonding and reducing GHG emissions.

Mona et al. [3] and Klimek-Kopyra et al. [35] note significant differences in the quality of biochar in terms of plant cultivation suitability. These authors stated that microalgae biochar was characterized by a higher sorption capacity, increasing the use of elements applied with fertilizers.

The aim of the research was to assess GHG emissions in soybean cultivation using biochar fertilizer in various doses and from various raw materials.

\section{Materials and Methods}

\subsection{Details of the Vegetation Experiment}

The experiment was located in Krakow, at the experimental station of the University of Agriculture (Latitude 50.084796 N, Longitude 19.853968 E). The experiment was set up on 10 April 2019 and the plants were harvested on 16 August 2020. The sowing was done in the soil with a clay sand grain composition. The experimental factor in the conducted experiment were the type of biochar and its dose. The field experiment included 3 doses of biochar at $40 \mathrm{Mg}, 60 \mathrm{Mg}$ and $80 \mathrm{Mg}$ per ha. The test plant was soybean Glicine max L, the variety Elegance F1. 0.8 million plants per hectare were sown, at $2.5 \mathrm{~cm}$ intervals. The methodology of integrated protection and soybean production was applied in plot management. The following agricultural treatments were applied: plowing, biochar application, mixing biochar with soil using an active aggregate $(3 \times)$, sowing fertilizers, sowing plants, mechanical weed control $(2 \times)$, mechanical harvesting, transport, drying of seeds.

The experiment was designed using the randomized block method, in four replications. The scheme of the experiment is given in Table 1.

Table 1. The scheme of the vegetation experiment.

\begin{tabular}{ccc}
\hline Treatments & Type of Biochar & Dose (Mg/ha) \\
\hline 1 & n/a & (control) \\
\hline 2 & from sunflower husk & 40 \\
\hline 3 & from sunflower husk & 60 \\
\hline 4 & from sunflower husk & 80 \\
\hline 5 & from forest biomass & 40 \\
\hline 6 & from forest biomass & 60 \\
\hline 7 & from forest biomass & 80 \\
\hline
\end{tabular}

\subsection{Weather Conditions and Soil Properties}

According to the weather station in Balice, the average annual precipitation from 2018-2019 was $401.9 \mathrm{~mm}$ and was higher by $48.7 \mathrm{~mm}$ than the 30-year standard (353.2 $\mathrm{mm}$ ) in the plant growing season (Figure 1). The year 2020 was more similar to the multiannual period. The amount of precipitation was then $337.3 \mathrm{~mm}$. In 2019, abundant precipitation and lower temperature in comparison to the multiannual period was reported. Precipitation in June was under the average from the multiannual period and led to soil draught. 2020 brought a deficiency in precipitation in March and April and abundant rain in May and June. 


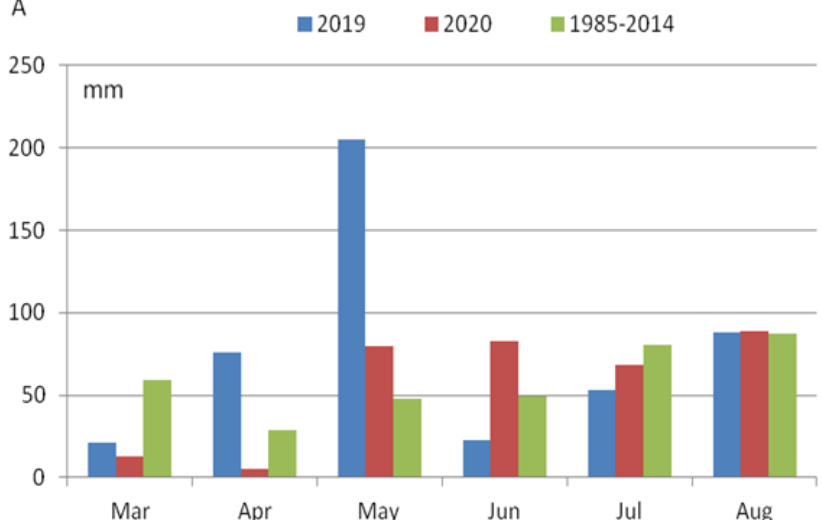

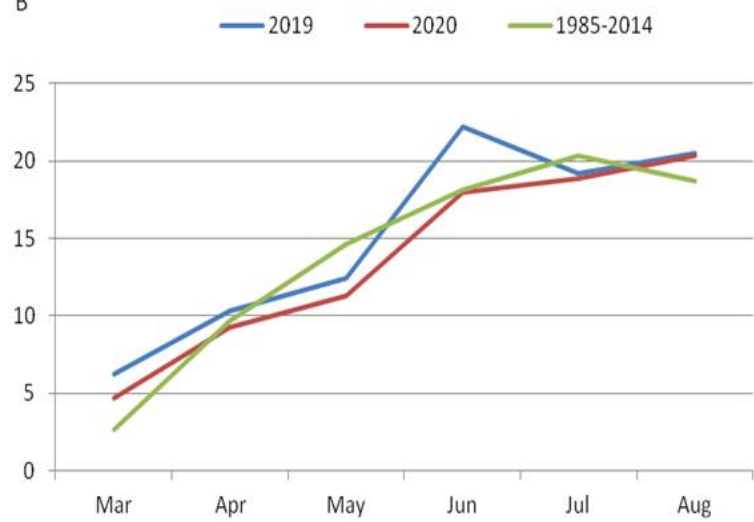

Figure 1. Average sum of precipitation (A) and temperature (B) in 2019 and 2020 and the long-term average from 1985-2014 (according to the Meteorological Station in Balice).

The analysis of the average monthly air temperature from March to August in 2018-2019 prove that the average values for years 2018-2019 were higher than the standards from March and June. In 2019 the average temperature in May was lower, whereas in June it was considerably higher in the investigated period in comparison to the multiannual period. In 2020 the average temperature was lower than the standard of the multiannual period from April to July. Only in March and August was a slight increase in the average temperature of the air above the standard for the multiannual period observed.

Before setting up the experiment, soil samples were collected and their basic parameters were determined, to estimate the yield potential. The soil $\mathrm{pH}$ was determined by the potentiometric method, and the content of organic carbon and total nitrogen was determined by elemental analysis using the Vario Max Cube by Elementar. The determination of mineral nitrogen was determined by distillation after prior extraction with a $1 \mathrm{~mol} \cdot \mathrm{dm}^{-3}$ solution of potassium sulphate. The content of the available forms of phosphorus and potassium was determined by the Egner-Riehm method. The content of assimilable forms of calcium and magnesium was determined by the Schaschabel method. The production potential of the habitat was estimated at $2.9 \mathrm{Mg}$ of seeds/ha. Prior to setting up the experiment, physicochemical and chemical properties of the soil were analyzed, determining the values for $\mathrm{pH}$, particle size distribution, organic matter content, mineral and Kiejdahl nitrogen content, as well as content of available forms of $\mathrm{P}, \mathrm{K}, \mathrm{Mg}, \mathrm{Ca}$.

The soil properties are given in Table 2. In the experiment, the same level of fertilization was adopted for all objects, which corresponded to the nutritional requirements of plants at the estimated level of the habitat's production potential. The levels of NPK fertilization were as follows: $30 \mathrm{~kg} / \mathrm{ha}, 70 \mathrm{~kg} / \mathrm{ha}$ and $100 \mathrm{~kg} / \mathrm{ha}$. All fertilizers were applied before sowing.

Table 2. Properties of the soil on which the experiment was conducted.

\begin{tabular}{|c|c|c|c|c|c|c|c|c|}
\hline \multirow{2}{*}{$\mathrm{pH}$ in $\mathrm{H}_{2} \mathrm{O}$} & \multirow{2}{*}{$\mathrm{pH}$ in $\mathrm{KCl}$} & N Total & C org & $\mathbf{N} \min$ & $\mathbf{P}$ & $\mathbf{K}$ & $\mathrm{Mg}$ & $\mathrm{Ca}$ \\
\hline & & \multicolumn{2}{|c|}{$(g / k g)$} & \multicolumn{5}{|c|}{ (mg/kg) } \\
\hline 6.73 & 6.28 & 0.116 & 1.33 & 32.1 & 99.4 & 81.9 & 42.01 & 836.9 \\
\hline
\end{tabular}

In terms of the number of objects, the scope of conducted research and geographical location, the experiment was planned based on the adopted qualitative and quantitative goals, as well as technical possibilities [36]. The selection of the test plant variety, individual fertilization variants, the scope of agricultural treatments, the level of irrigation and the time frame of the experiment was established based on a risk analysis, according to the ISO 31000: 2018 standard. The identified risk was the impact of the above-mentioned risk 
factors on the yielding of plants in specific environmental conditions. The scope of the investigation was determined based on a literature study, as was the selection of GHG emission sources.

\subsection{Qualitative Characteristics of Biochar}

Two types of biochar were used in the experiment: biochar from sunflower husk and from the waste biomass of the wood industry (wood chips). In the production of biochar, identical process parameters were used, regardless of the raw material, i.e., pyrolysis at $450-550{ }^{\circ} \mathrm{C}(36-37)$ for $15-20 \mathrm{~min}$. The biochar parameters were as follows: specific surface area $-80.9\left(\mathrm{~m}^{2} / \mathrm{g}\right)$, $\mathrm{pH} \mathrm{Kcl}-9.2$, density $(\mathrm{g} / \mathrm{cm})-1.4$, ash content $(\%)-35.4$, organic carbon $(\%)-22.5$. Biochar is characterized by specific porosity: the average pore radius was $0.24 \mu \mathrm{m}$, total surface of the pore was $19.01 \mathrm{~m}^{2} / \mathrm{g}$, and the total porosity was $75.92 \%$. The biochar was prepared for SEM by fine grinding. The sample was then transferred under vacuum and imaged by SEM (Zeiss Ultra Plus, Jena, Germany) at $5 \mathrm{kV}$.

\subsection{System Boundy}

The experiment was carried out according to the following scheme:

1. Defining the strategic goal;

2. Selection of the experiment factors (a two-way experiment was selected);

3. Selection of the experiment plant (soybean as a plant with high GHG emissions);

4. Selection of the experiment site (a geographic system boundary); the experiment was carried out in the vicinity of large-area vegetable cultivation;

5. The applied treatments (excluding the experimental factor) were selected based on the recommendations of the Integrated Plant Production methodology and were based on production practices in the research area;

6. Determining the levels of experimental factors; 40,60 and $80 \mathrm{Mg} / \mathrm{ha}$ of biochar additives were used;

7. The boundary of the system was selected based on a literature study and a risk analysis in the context of the adopted goal, according to the ISO 31000: 2018 standard.

The system boundary is shown in Figure 2 and included:

1. Production of fertilizers used in plant cultivation;

2. Energy consumption for field work on the farm;

3. Soil emissions (direct and indirect, related to fertilizer use);

4. Emissions from the management of crop residues and from the mineralization of soil organic matter;

5. Emissions related to biochar production;

6. Emissions related to seed production;

\subsection{Life Cycle Calculation Methodology}

One of the methods of comprehensive and multifaceted assessment of the quality system is to prepare a product life cycle that takes into account the use of energy, means of production as well as renewable and nonrenewable environmental resources [37]. However, the development of a reliable and universal method is very difficult, since farms operate in a specific economic, social and climatic framework, which significantly affects the assessment carried out and is very difficult to interpret. Therefore, the evaluation of agricultural systems is very often done based on a selected part of the activity [38].

To determine the level of the environmental impact of soybean production, the following standards were applied: ISO 14040: "Environmental Management-Life Cycle Assessment-Principles and framework" and ISO 14044: "Environmental Management-Life Cycle Assessment-Requirements". The analysis was performed according to the recommendations contained in the document [39]. Product transport, packaging, use of agricultural tools, and marketing were excluded from the investigation. The production and transport of seedlings were also excluded from the process due to the lack of data on this process. The adopted functional unit was $1 \mathrm{t}$ of commercial product, and the timeframe for the 
system was one year. The potential to generate the greenhouse effect was estimated based on the GHG emissions expressed as a carbon dioxide equivalent $\left(\mathrm{CO}_{2 \text { eq }}\right)$.

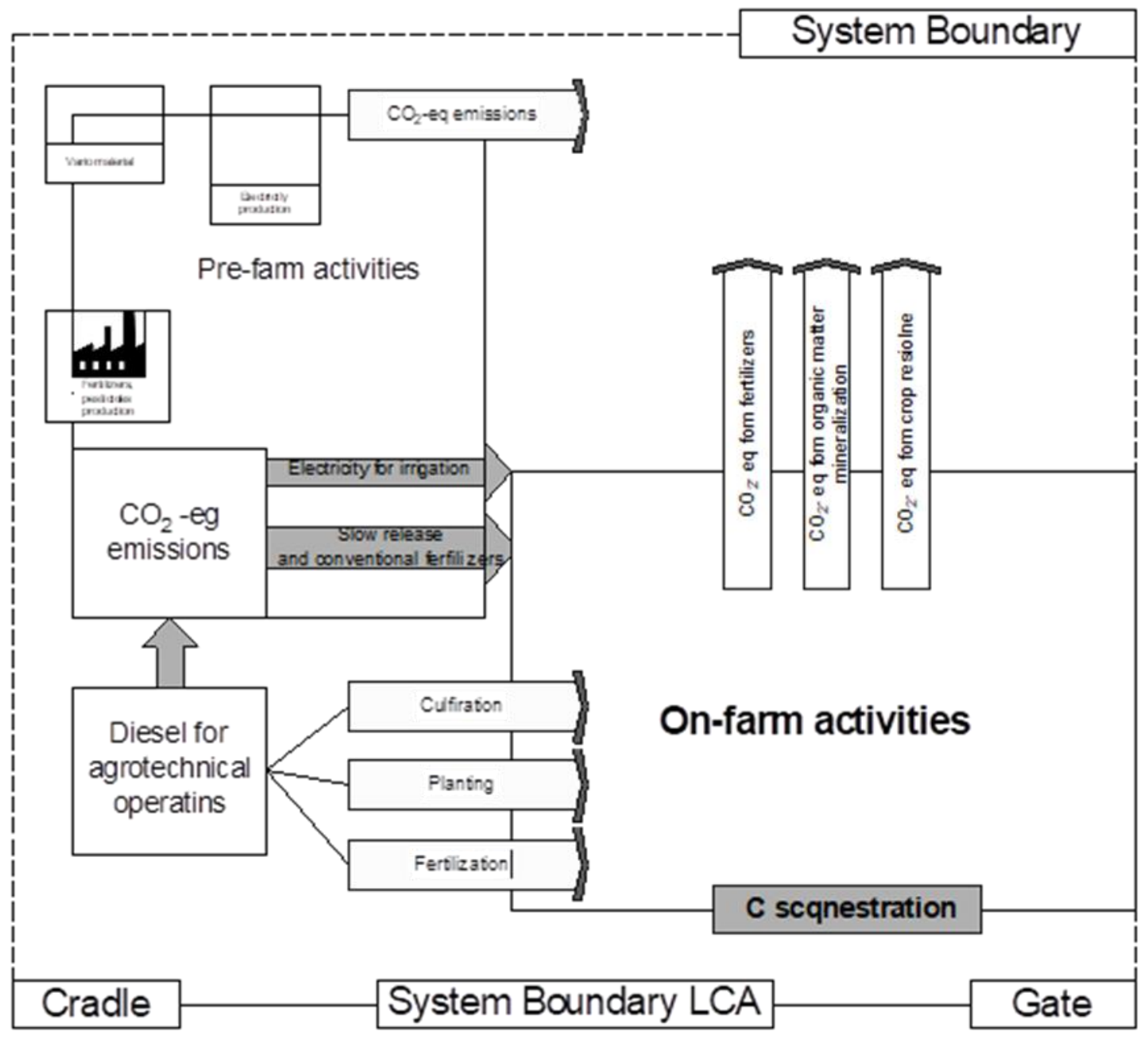

Figure 2. System boundaries of the experiment.

As part of the execution of the adopted research objective, the life cycle for the production of biochar from two types of waste (sunflower husk and wood chips) was calculated. The functional unit was $1 \mathrm{Mg}$ of biochar.

Input data for the calculation of the GHG emission value came from 3 experimental objects with plants fertilized with biochar produced from sunflower husk, and from 3 objects where biochar produced from wood chips was used.

Three types of mineral fertilizers were used for fertilization, for which the level of GHG emissions was adopted according to the data in the literature. The GHG emission level for nitrogen production in ammonium nitrate was adopted at $7.99 \mathrm{~kg} \mathrm{CO}_{2} / \mathrm{kg} \mathrm{N}$, for triple superphosphate at $0.36 \mathrm{~kg} \mathrm{CO}_{2} / \mathrm{kg} \mathrm{P}_{2} \mathrm{O}_{5}$ while for potassium chloride it was at $0.56 \mathrm{~kg} \mathrm{CO} / 2 / \mathrm{kg} \mathrm{K}_{2} \mathrm{O}$ [40]. The amount of ammonia emitted to the atmosphere was calculated based on the guidelines provided by [41]. Emission factors for crop residues were calculated based on the amount of by-product in soybean cultivation. Based on the experimental results, it was estimated that in soybean cultivation the ratio of commercial yield after drying to by-products and crop residues ranged from $0.78 \%$ to $0.89 \%$ depending on the research object. The content of carbon fraction in the dry matter of crop residues was adopted based on the analyses. Depending on the research object, it ranged from $48.72 \%$ to $54.23 \%$ and the nitrogen content in the crop residues ranged from $1.82 \%$ to $2.32 \%$ per dry matter. The level of decomposition of crop residues was estimated at $25 \%$. The 
amount of carbon dioxide and nitrogen oxide emissions from crop residues from soil was calculated according to the methodology included in the IPCC Report [42]. The amount of nitrogen emitted in the form of nitrogen oxides was adopted at $1.25 \%$ [43]. The $\mathrm{N}-\mathrm{N}_{2} \mathrm{O}$ emission value was converted to $\mathrm{CO}_{2}$ eq by multiplying its quantity by the value of the global warming potential coefficient, i.e., 292 [44]. The soil organic matter mineralization index adopted in the analysis was at $1.6 \%$. Nitric oxide emission values resulting from nitrogen transformations in soil were calculated according to the methodology of the IPCC Report [42]. GHG emissions from the combustion of fossil fuels used for agricultural treatments were also taken into account in soybean life cycle assessment. Fuel consumption in individual agricultural treatments is presented in Table 3.

Table 3. Energy consumption and GHG emissions related to agricultural treatments.

\begin{tabular}{cccc}
\hline $\begin{array}{c}\text { Type of Agrotechnical } \\
\text { Treatment }\end{array}$ & $\begin{array}{c}\text { Fuel Use } \\
\left(\mathbf{d m}^{\mathbf{3}} \mathbf{)}\right.\end{array}$ & $\begin{array}{c}\text { Energy Use } \\
\mathbf{( \mathbf { M J } )}\end{array}$ & $\begin{array}{c}\mathbf{C O}_{\mathbf{2}} \text { Emissions } \\
\mathbf{( k g )}\end{array}$ \\
\hline Tillage & 57 & 2308.5 & 221.1 \\
\hline Mineral fertilization $(\times 2)$ & 15.3 & 619.7 & 59.4 \\
\hline Cultivation with an aggregate & 28.2 & 1142.1 & 109.4 \\
\hline Sowing soybeans & 25.2 & 1020.6 & 97.8 \\
\hline Mechanical weed control $(\times 3)$ & 43.8 & 1773.9 & 169.9 \\
\hline Mechanical harvesting & 16.5 & 668.3 & 64.0 \\
\hline $\begin{array}{c}\text { Biochar application and mixing } \\
\text { it with the soil }(\mathrm{MJ} / \mathrm{Mg})\end{array}$ & 3.2 & 129.4 & 12.04 \\
\hline Transport to the farm $(\mathrm{t} / \mathrm{km})$ & 0.59 & 23.9 & 2.3 \\
\hline Drying soybeans $(\mathrm{MJ} / \mathrm{t})$ & & 482 & 45.46 \\
\hline
\end{tabular}

Fuel consumption for individual treatments was calculated based on the data presented by Wójcik [45]. On the other hand, the emissions from diesel combustion in farm tractors were adopted at $3.864 \mathrm{~kg}$ of $\mathrm{CO}_{2} / \mathrm{dm}$ fuel, based on the data provided by the EPA Report [46]. Due to the low amount of nitrogen oxides and methane emitted during diesel combustion in farm tractors, this source of GHG was omitted, as recommended by the EPA Report [46]. The energy consumption for drying the soybeans was based on [47]; the moisture level of the soybeans during harvest was 19.2\%. As part of post-harvest activities, seeds were dried to a moisture content of $15 \%$ at an energy expenditure of $0.42 \mathrm{GJ} / \mathrm{Mg}$ of seed weight. According to the methodology provided by FAO (2017), the amount of nitrogen emitted into the atmosphere from mineral fertilization is $1 \%$ direct emission and $0.27 \%$ of nitrogen dissipated in the environment. The amount of nitrogen oxides emitted from nitrogen diffused in mineral fertilizers was estimated at $0.75 \%$ of the total nitrogen not used by plants during the growing season [48] (Tables 4 and 5).

Table 4. Selected parameters of the torrefaction process and the type of biochar used in the experiment.

\begin{tabular}{cccc}
\hline Following Parameters & Unit & Sunflower Husk Biomass & $\begin{array}{c}\text { Wood } \\
\text { Biomass }\end{array}$ \\
\hline Efficiency of the torrefaction process & \% by weight of the raw material & 35.42 & 38.83 \\
\hline $\begin{array}{c}\mathrm{CO}_{2} \text { emissions related to the } \\
\text { preparation of the raw material }\end{array}$ & $\mathrm{kg} \mathrm{CO}$ eq $/ \mathrm{Mg}$ of biochar & 117 & 156 \\
\hline Organic carbon content & $\%$ & 85.32 & 83.89 \\
\hline Stable carbon content in biochar & $\%$ of total carbon & 79.87 & 77.41 \\
\hline
\end{tabular}


Table 5. $\mathrm{CO}_{2}$ emissions from fertilizers $\left(\mathrm{CO}_{2}\right.$ eq $/$ ha).

\begin{tabular}{ccccc}
\hline Treatments & A & B & C & D \\
\hline 1 & 628.6 & 810.5 & 685.3 & 0.0 \\
\hline 2 & 628.6 & 814.6 & 923.3 & 103.2 \\
\hline 3 & 628.6 & 900.8 & 1550.9 & 154.8 \\
\hline 4 & 628.6 & 846.2 & 1346.1 & 206.5 \\
\hline 5 & 628.6 & 840.6 & 1068.1 & 134.4 \\
\hline 6 & 628.6 & 897.1 & 1564.6 & 201.6 \\
\hline 7 & 628.6 & 873.5 & 1479.2 & 268.9 \\
\hline
\end{tabular}

A- $\mathrm{CO}_{2}$ eq from fertilizers and seeds [40], B-CO $\mathrm{CO}_{2}$ emission from fuel combustion (Wang et al. 2012), $\mathrm{C}-\mathrm{CO}_{2}$ emission from harvest residues and mineralization of organic matter [42,43], D- $\mathrm{CO}_{2}$ emission related to the production and use of biochar [49-51].

The value of the carbon footprint for biochar production was adopted according to the data presented by [49] at $105 \mathrm{~kg} \mathrm{CO}_{2} \mathrm{eq} / \mathrm{Mg}$ biochar. The value of transportrelated emissions was adopted at $32 \mathrm{~kg} \mathrm{CO} 2 \mathrm{eq} / \mathrm{Mg}$ biochar, provided the transport of raw materials and products was within $40 \mathrm{~km}$ from the installation. The efficiency of the torrefaction process for sunflower husks was $35.42 \%$, and for wood biomass $38.83 \%$. The stable carbon content in the sunflower husk biochar was $79.87 \%$, and in wood biomass it was $77.41 \%$. GHG emissions related to biochar production were calculated based on the mass and energy balance of the biochar production process and literature data provided by Llorach-Massan [49]. The time frame for the effect of the applied biochar, i.e., the period in which $50 \%$ of the applied biochar should decompose, is 50 years [50,51].

\section{Results and Discussion}

\subsection{Soybean Yield and Total $\mathrm{CO}_{2}$ Emissions Depending on the Doses of Biochar Applied to the Soil}

To verify the effect of biochar fertilization on soybean yield and total $\mathrm{CO}_{2}$ emissions, a one-way analysis of variance was performed. The significance of the differences between the compared variables is illustrated in the last column (Table 6). As shown by the data, there are significant differences in the soybean yield and total $\mathrm{CO}_{2}$ emissions depending on the applied doses of biochar.

Table 6. Results of the analysis of variance in single classification: soybean yield and total $\mathrm{CO}_{2}$ emissions depending on the doses of biochar applied to the soil.

\begin{tabular}{cccc}
\hline Sum of Squares & Mean of Squares & Test F & $p$ \\
\hline \multicolumn{4}{c}{ Soybean yield } \\
\hline 15.1151 & 2.5192 & 22.184 & 0.000 * \\
\hline \multicolumn{4}{c}{ Total CO C $_{2}$ emissions } \\
\hline *-significant dependence at $\alpha=0.05$. & 13.168 & 0.0001 * \\
\hline
\end{tabular}

The assumption that the dose of biochar application affects the yield of soybeans and the total emission of $\mathrm{CO}_{2}$ was confirmed by statistical analysis (Table 6). The demonstration of statistical significant differences within the above-mentioned indicators shows a significant correlation between the size of the biochar dose and the yield of soybeans and the total emission of $\mathrm{CO}_{2}$.

Figure 3 is a graphic presentation of the results of the analysis of variance of soybean yield per the type and dosage of biochar. As demonstrated, the type and dosage of biochar has a large impact on the yield of soybean. Soybean fertilized with $60 \mathrm{Mg}$ of biochar per hectare, both types, showed the best yield. This tendency was not confirmed with the use of $80 \mathrm{Mg}$ per hectare biochar doses. To better illustrate the obtained results, Tukey's test 
was carried out to determine homogeneous groups within the studied variable. The test results are presented in Table 7.

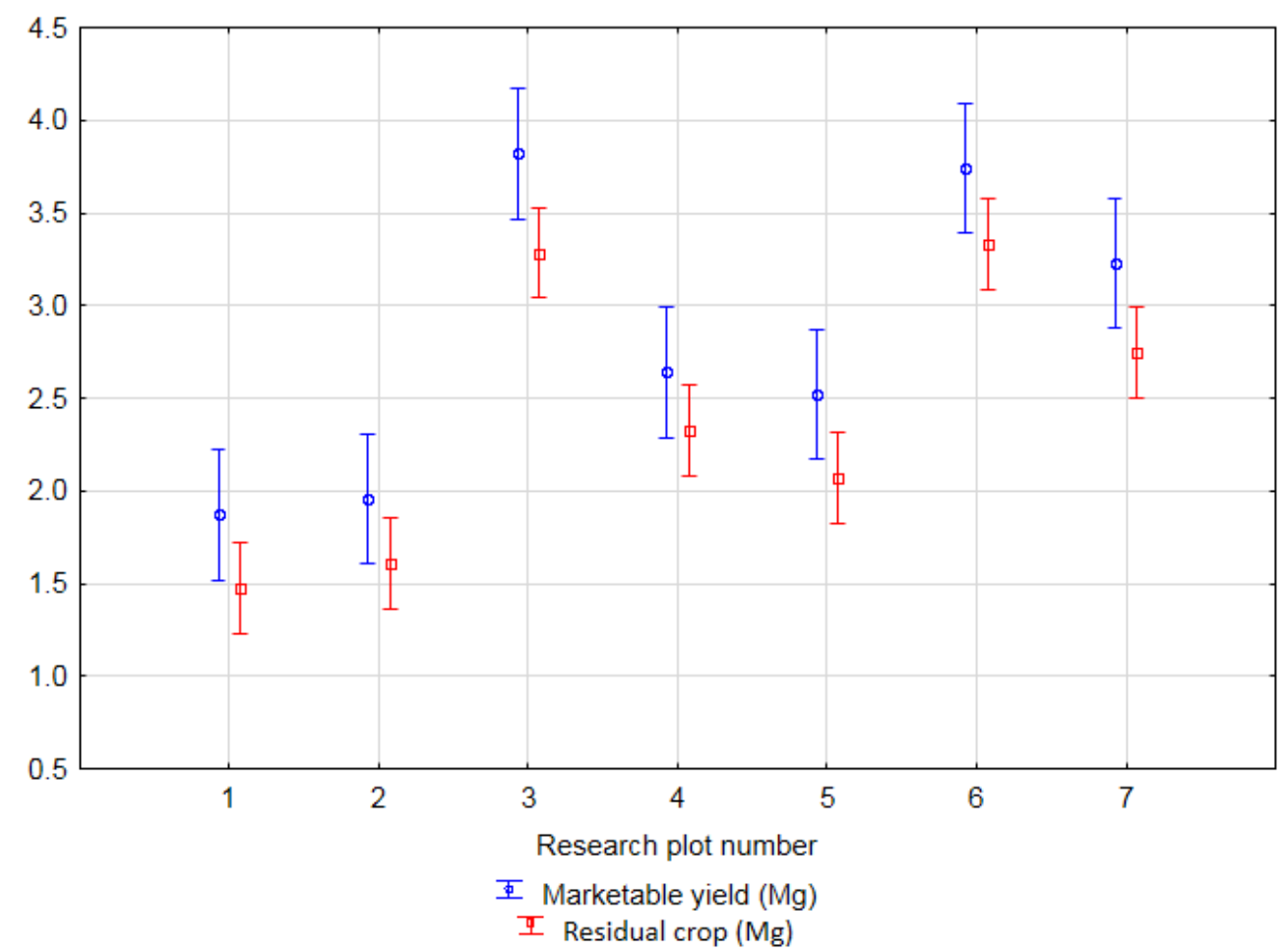

Figure 3. Average values of soybean yield $(\mathrm{Mg})$ depending on the type and dosage of biochar.

Table 7. The results of Tukey's test for groups of significantly homogeneous grouping factor (****) of biochar dose and soybean yield.

\begin{tabular}{ccccc}
\hline Treatments & Marketable Yield $\mathbf{( M g})$ & $\mathbf{1}$ & $\mathbf{2}$ & $\mathbf{3}$ \\
\hline 1 & 1.870 & $* * * *$ & & \\
2 & 1.960 & $* * * *$ & & \\
5 & 2.520 & $* * * * * * *$ & $* * * *$ & \\
4 & 2.640 & $* * *$ & $* * * *$ & $* * * *$ \\
7 & 3.230 & & & $* * * *$ \\
6 & 3.740 & & & $* * * *$ \\
3 & 3.820 & & \\
\hline
\end{tabular}

Tukey's test confirmed that there are homogeneous groups of the studied variable and that they include statistically significant relationships. Soybean plants yielded significantly better after applying a biochar dose of $60 \mathrm{Mg}$ per hectare compared to the control, regardless of the type of biochar used. In the objects where biochar fertilization was applied at 40 tons, the yield of soybean was comparable to that of the control plots.

Figure 3 graphically presents the obtained results of the univariate analysis of variance for the total $\mathrm{CO}_{2}$ emissions for doses and types of biochar applied. The application rates at $60 \mathrm{Mg}$ per hectare (Figure 2) emission can be clearly seen. The highest total $\mathrm{CO}_{2}$ emissions were recorded in an object where sunflower husk biochar was used at a dose of $40 \mathrm{Mg}$ per hectare.

The Tukey test performed for total $\mathrm{CO}_{2}$ emissions showed that the objects fertilized with biochar at 60 tons per hectare formed a homogeneous group with the lowest total $\mathrm{CO}_{2}$ emission. The homogeneous group with the highest $\mathrm{CO}_{2}$ emissions consisted of objects with sunflower husk biochar doses of 40 and 80 tons per hectare, and a control object. This result proves a significant impact of biochar dosing and type on the total $\mathrm{CO}_{2}$ emission (Table 8). 
Table 8. Results of Tukey's test for groups of the significantly homogeneous grouping factor (****) of biochar dose and soybean yield.

\begin{tabular}{cccccc}
\hline Treatments & Total Emission $\left(\mathbf{k g} / \mathrm{CO}_{2}\right)$ & $\mathbf{1}$ & $\mathbf{2}$ & $\mathbf{3}$ & $\mathbf{4}$ \\
\hline 3 & 846.9 & & $* * * *$ & & \\
6 & 880.2 & & $* * * * * * * * * * * * *$ & $* * * *$ & \\
7 & 1006.2 & $* * * *$ & & $* * * *$ & \\
5 & 1060.2 & $* * * *$ & & & $* * * *$ \\
1 & 1136.0 & $* * * *$ & & & $* * * *$ \\
4 & 1146.7 & & & & $* * * *$ \\
2 & 1260.1 & & &
\end{tabular}

The obtained results were subject to variance analysis. The significance of the differentiation of mean values was determined using Tukey's test $(\alpha \leq 0.05)$. The Statistica 13 program (TIBCO Software Inc., Palo Alto, CA, USA) was used to statistically analyze the results.

Processing waste organic matter into biochar before introducing it into the soil is an effective method of stabilizing carbon compounds and increasing the level of sequestration of this element in soil organic matter [52,53]. The problem pointed out by, e.g., [54,55] could be biochar contamination with heavy metals or polyunsaturated aromatic hydrocarbons. The results of the calculations show a significant differentiation in the total GHG emissions converted into $\mathrm{CO}_{2}$ eq for the adopted system boundary. The factor differentiating the compared production technologies was the type of biochar and its dose. The adopted conversion unit was $1 \mathrm{t}$ of commercial product after drying to a moisture level of $15 \%$. The introduction of biochar into the soil statistically significantly affected the yield of soybeans. The commercial yield of the object without the addition of biochar was $1.87 \mathrm{Mg}$ of seeds, the lowest value among all the objects (Figure 3).

The addition of sunflower husk biochar at $40 \mathrm{Mg} /$ ha did not change the yield. However, increasing the amount of this material to $60 \mathrm{Mg} / \mathrm{ha}$ increased the yield by $100 \%$ compared to the result obtained in the control object. A further increase in the dose of biochar resulted in a reduction of plant yield; however, higher yields were observed in each object with the addition of biochar as compared to the control object. A lower dose impact on the level of plant yield was found in research objects with the addition of wood chip biochar. The values of this parameter ranged from 2.52 to $3.74 \mathrm{Mg} / \mathrm{ha}$ of dry seeds. From the point of view of plant yield, wood chip biochar proved to be a more useful material. The type of raw material used for the production of biochar plays an important role in the formation of the properties of biochar in terms of its functionality [23]. Literature data indicate that the addition of biochar to soil could have a positive effect on the yield of plants, but to a lesser extent than indicated by the results of the author's own research. Floe et al. [56] showed that the use of biochar in maize cultivation increased its yield by 10 to $15 \%$ compared to cultivation without the use of biochar, depending on the availability of water. Ndor et al. [57] report that the use of biochar at $5 \mathrm{Mg} /$ ha increased the yield of maize by $40 \%$ as compared to the object without biochar. Addition of biochar at $10 \mathrm{Mg} \mathrm{ha}^{-1}$ increased the yield by $66 \%$ compared to the control object. These authors point out that the addition of biochar to the soil changes its properties, e.g., air and water conditions, $\mathrm{pH}$, and the availability of nutrients for plants. Similarly, Krause et al. [58] and Gong et al. [53] indicate that the yield potential of biochar is associated with the improvement of plant growth conditions and an increased availability of nutrients. Increasing the yield of plants at the same consumption level of production means directly reducing GHG emissions from plant production. Wang et al. [59] found that the addition of biochar to soil significantly reduced the GHG emissions from agrocenoses.

Sánchez-García et al. [60] also indicate that biochar added to the soil had a positive effect on nitrogen oxide emissions in cabbage cultivation. The reduction of GHG emissions was most noticeable in the periods with increased emissions. The authors stated that the key element that affected the level of nitrogen oxide emissions was the change in air-water properties of the soil after the addition of biochar, which influenced the level of microbial activity in the soil. 


\subsection{Emission Sources in the Total GHG Emission Related to Soybean Production}

The results of the experiments indicate a significant impact of the proposed technological strategies for soybean cultivation on the formation of GHG emissions from both direct and indirect sources. The total GHG emissions given as $\mathrm{CO}_{2}$ eq ranged from 846.9 to $1260.1 \mathrm{~kg}$ of $\mathrm{CO}_{2} / \mathrm{Mg}$ of the weight of the commercial product (Figure 4).

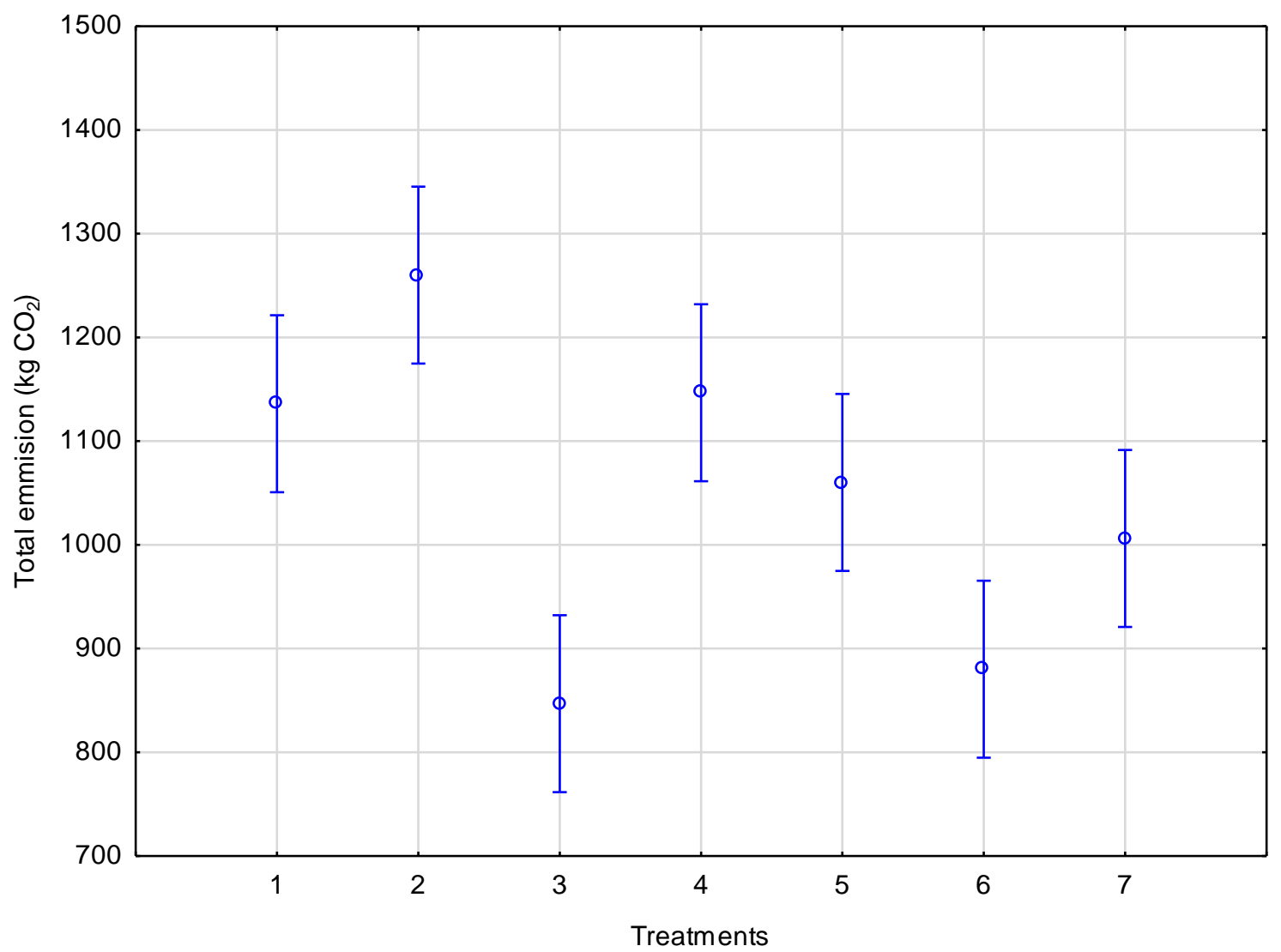

Figure 4. Average values of total emissions of $1 \mathrm{~kg} \mathrm{CO}$ depending on the type and dosage of biochar.

The lowest value of this parameter was obtained for the object with $60 \mathrm{Mg}$ of sunflower husk biochar. The GHG emission value for the control object without biochar was $1136 \mathrm{~kg} \mathrm{CO} / \mathrm{Mg}$. From the point of view of environmental efficiency, the best effects for the adopted system boundary were obtained in the variant with the addition of $60 \mathrm{Mg}$ of biochar, both when the raw material was sunflower husk and wood chips. A further increase in the amount of biochar resulted in a reduction in the yield of plants, which affected the results of GHG emissions. Even taking into account the emission of GHGs into the atmosphere related to the process of biochar production, as well as the transport of raw materials and the product itself, the results of the presented studies indicate that the introduction of such materials into the soil is environmentally justified. The results obtained in the authors' own research in specific variants of the experiment are much higher compared to the data presented by other authors. The factor with the greatest impact on the GHG emissions was the level of crop yield. The effects comparable to the data in the literature were obtained in the treatment with the addition of biochar at $60 \mathrm{Mg} / \mathrm{ha}$ (Figure 3). Zortea et al. [61] report the value of $\mathrm{CO}_{2}$ eq emissions from soybean production in basil at $734 \mathrm{~kg} \mathrm{CO} / \mathrm{Mg}$ of seeds. These authors report that over $40 \%$ of the total emissions are related to emissions from soil, both from the fertilizers used and the mineralization of organic matter. Rajaeifar et al. [62] report the level of GHG emissions from soybean cultivation at the level observed in objects with the addition of biochar at $60 \mathrm{Mg} / \mathrm{ha}$. Geraldes Castanheir and Freire [63] calculated the $\mathrm{CO}_{2}$ eq emissions for soybean cultivation 
at $200-400 \mathrm{~kg}$ per $\mathrm{Mg}$ of dry weight of seeds. These authors did not include within the system boundaries the emissions related to the mineralization of organic matter and crop residues. Increasing the yield of plants, which is associated with increasing the efficiency of nutrient and water use, indicates a positive assessment of soil enrichment with biochar in terms of production economics. According to the data presented by Lehmann et al. [50], Llorach-Massana et al. [49] or Wang et al. [63], biochar introduced into the soil reduces the emission of nitrogen oxides and carbon monoxide by increasing the sorption capacity of these gases. This element was not taken into account in these studies; however, it should not be omitted when developing recommendations for the management of organic carbon resources in agricultural soils. Increasing the efficiency of the use of plant nutrients is a strategic element of sustainable development in agriculture [64-66] and increasing the amount of organic matter in soils is one of the most environmentally effective methods of intensifying plant production $[12,16,32,63]$. Figure 5 demonstrates the percentage share of individual GHG sources in the total emission for the adopted system boundary. The sources were divided into 5 groups: (i) Burning fuels; (ii) Production and use of fertilizers and seeds; (iii) Ghg emissions from the soil resulting from the decomposition of crop residues and soil organic matter; (iv) Emissions from energy consumed to dry seeds; and (v) Emissions related to the production and use of biochar as well as its distribution in the soil ecosystem.

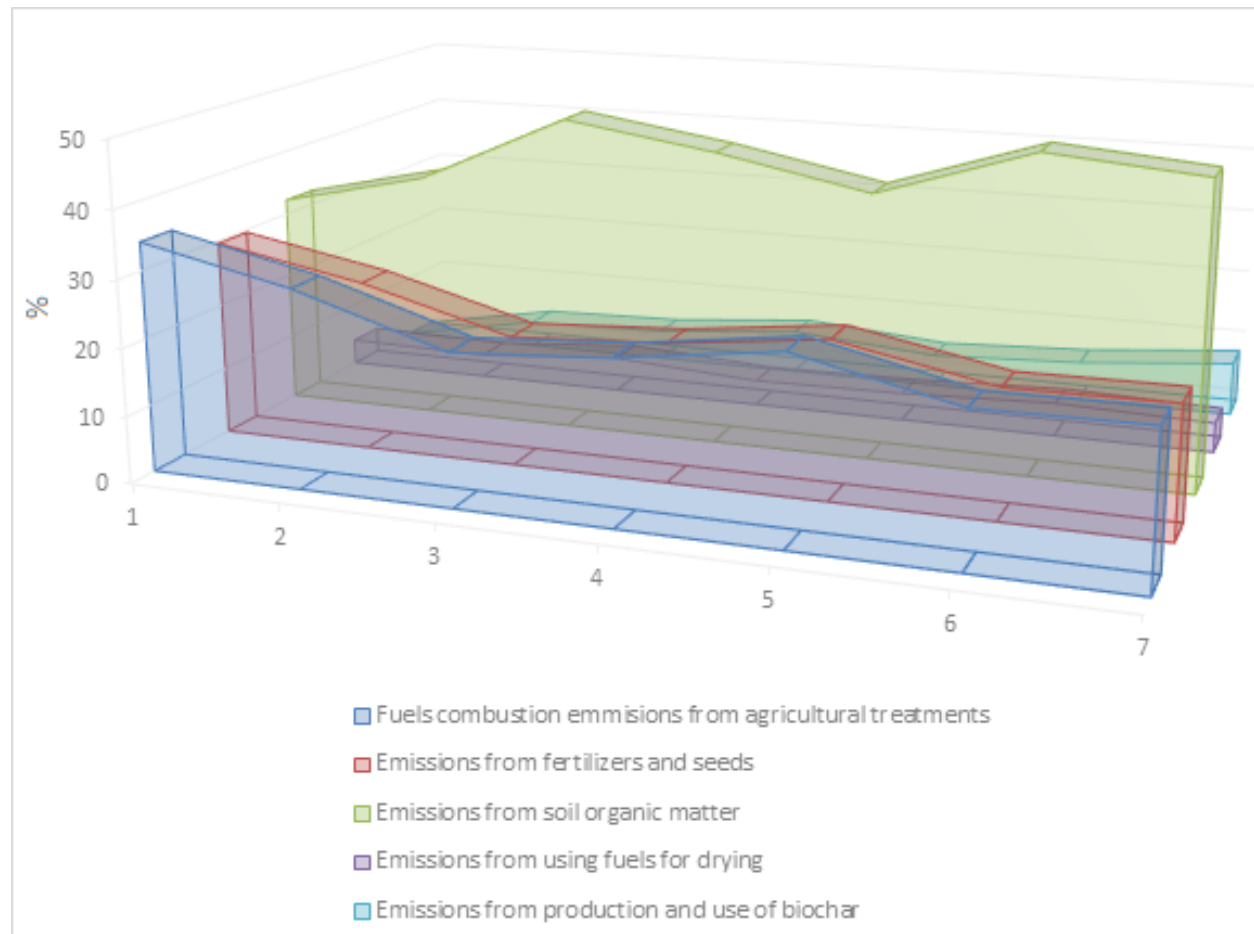

Figure 5. Share of individual emission sources in the total GHG emission related to soybean production.

Among all the groups of sources of GHG emissions in soybean cultivation, in all research objects the emission from mineralization of soil organic matter, both from crop residues and from mineralization of humus compounds, had the highest share. The level of GHG emissions in individual research objects ranged from 366.4 to $509.9 \mathrm{~kg}$ of $\mathrm{CO}_{2} / \mathrm{Mg}$ of seeds (Figure 6). The highest value of this parameter was found in the objects with the highest addition of biochar, while the lowest emission from this source was observed in the control object. The emission from this source constituted $32.26 \%$ of the total emission in the control object and 47.94 in the object with the addition of sunflower husk biochar at $60 \mathrm{Mg} /$ ha (Figure 3). Fertilization was the second most important source of GHG emissions. Costantini and Bacenetti [67] report that the GHG emissions for soybean 
cultivation resulting from the use of fertilizers constituted $45 \%$ of the total calculated emissions. Emissions from the decomposition of crop residues reported by these authors accounted for approximately $13 \%$ of the total production emissions. The production and use of fertilizers, especially nitrogen fertilizers, is the most important source of GHG emissions in agricultural production $[68,69]$. This is due to the high energy expenditure in ammonia synthesis and the emission of unused nitrogen to the atmosphere in the form of nitrogen oxide, which has an almost 300 times greater potential to generate the greenhouse effect compared to carbon dioxide. In the cultivation of legumes, with optimal soil properties and a sufficient supply of macro- and microelements, generally less nitrogen fertilization is used, as this element can be bound by symbiotic bacteria. Promoting the production of legumes is therefore an element of reducing not only the amount of GHG emissions, but also of the energy consumption in the food production process, which is now a priority in the optimization of production processes [70].
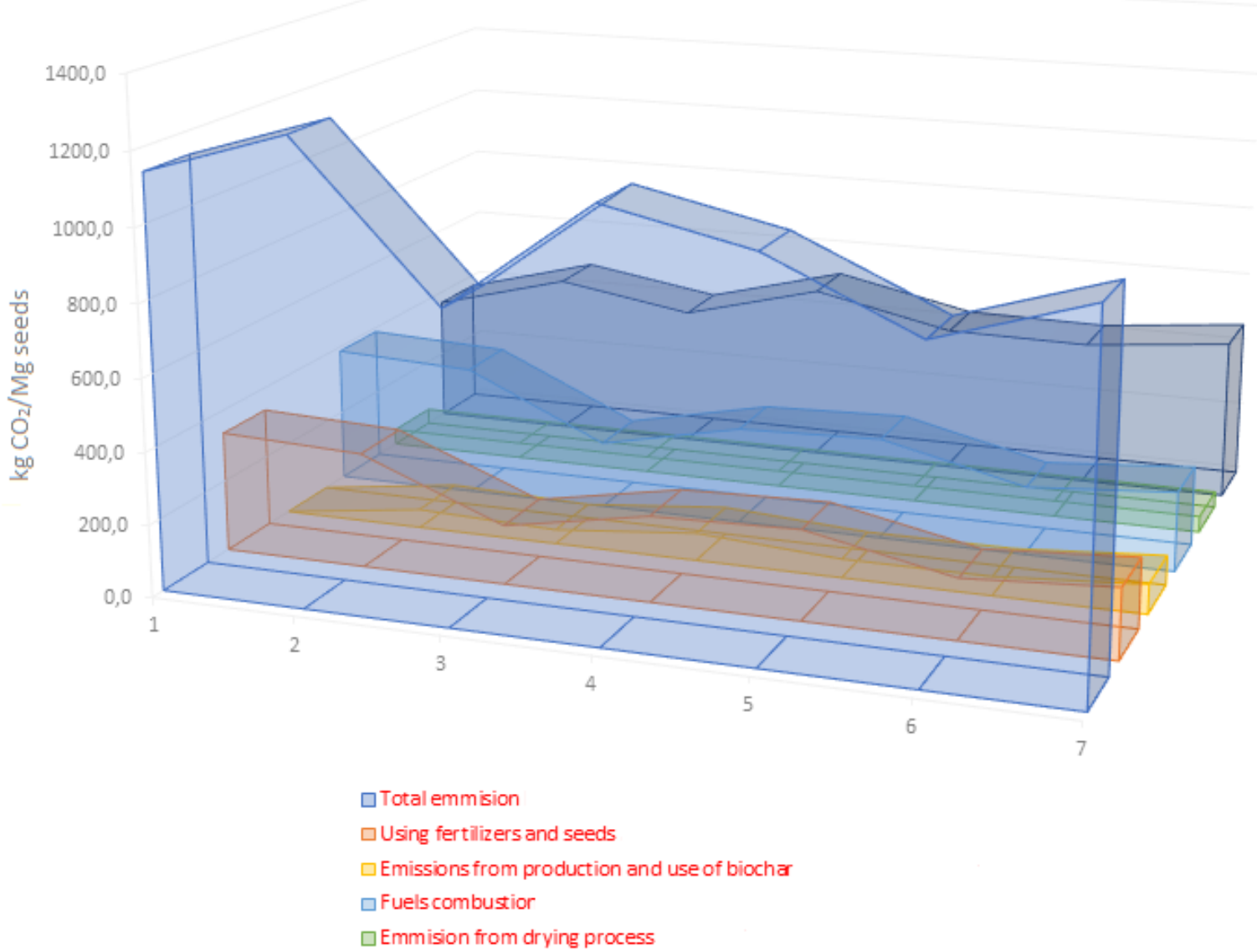

Figure 6. Share of individual emission sources in the total GHG emission related to soybean production $(\mathrm{kg} \mathrm{CO} / \mathrm{kg})$.

The outcome of the conducted studies proves a positive environmental impact of biochar application as a soil improver in case of soybean cultivation. Soil additives in the form of biochar resulted in a statistically significant increase in yield and reduction of greenhouse gases emission per accepted functional unit. Biochar production and application costs are one of the most important factors limiting the biochar use in agriculture. Latawiec et al. [21] indicate that there is no economic profitability in biochar application as it improved in soybean cultivation in the amount of 40,60, and $80 \mathrm{Mg} / \mathrm{ha}$. These authors emphasise that the popularity of biochar application as a soil enhancer is determined by subsidy programs for farms, which introduce biochar to soil. On the other hand, Majumder et al. [71] and Owsianiak et al. [72] draw attention to the need of searching 
for energetically effective methods of the conversion of biomass into biochar in order to increase its use in agriculture. According to these authors, the use of low-emission biomass torrefaction methods will result in the considerable increase in popularity of biochar application as a soil fertilizer.

\section{Conclusions}

1. The introduction of biochar to the soil had a statistically significant effect on the level of soybean yield.

2. The use of biochar in soybean cultivation resulted in a $25 \%$ reduction in GHG emissions compared to the object without the biochar addition. The amount of GHG emissions for soybeans ranged from 846.9 to $1260.1 \mathrm{~kg}$ of $\mathrm{CO}_{2} / \mathrm{Mg}$.

3. The impact of the type of biochar raw material on the yield and the level of GHG emissions per functional unit of the product was identified.

4. From the environmental and production perspective, the addition of biochar at $60 \mathrm{Mg} / \mathrm{ha}$ is the most advantageous. A further increase in the addition of biochar was related to a decrease in the plant yield and an increase in GHG emissions.

5. Introducing biochar to soil can be an effective improvement of the economic and environmental efficiency of plant production, as it increases the plant's use of nutrients and intensifies carbon sequestration in soils.

Author Contributions: M.K. was responsible for funding acquisition and the design of the experiment, while J.S., M.N. were responsible for data statistical analyses. M.K., M.N., A.K.-K., J.S., M.G., U.S., A.E.L., R.K., R.Z., A.K. and M.W., wrote the first draft of the article and all authors reviewed, edited and accepted the final manuscript. All authors have read and agreed to the published version of the manuscript.

Funding: This work was financed by the National Centre for Research and Development (NCBiR) under Grant No. BIOSTRATEG3/345940/7/NCBR/2017.

Conflicts of Interest: The authors declare no conflict of interest.

\section{References}

1. Chowaniak, M.; Głąb, T.; Klima, K.; Niemiec, M.; Zaleski, T.; Zuzek, D. Effect of tillage and crop management on runoff, soil erosion and organic carbon loss. Soil Use Manag. 2020, 36, 581-593. [CrossRef]

2. Niemiec, M.; Komorowska, M.; Mudryk, K.; Jewiarz, M.; Sikora, J.; Szelag-Sikora, A.; Rozkosz, A. Evaluation of the Fertilizing Potential of Products Based on Torrefied Biomass and Valorized with Mineral Additives. In Renewable Energy Sources: Engineering, Technology, Innovation; Wróbel, M., Jewiarz, M., Szlęk, A., Eds.; Springer: Cham, Switzerland, 2020. [CrossRef]

3. Mona, S.; Malyan, S.K.; Saini, N.; Deepak, B.; Pugazhendhi, A.; Kumar, S.S. Towards sustainable agriculture with carbon sequestration, and greenhouse gas mitigation using algal biochar. Chemosphere 2021, 275, 129856. [CrossRef]

4. Agegnehu, G.; Srivastava, A.; Michael, A.K.; Bird, I. The role of biochar and biochar-compost in improving soil quality and crop performance: A review. Appl. Soil Ecol. 2017, 119, 156-170. [CrossRef]

5. Klimek-Kopyra, A.; Bacior, M.; Zając, T. Biodiversity as a creator of productivity and interspecific competitiveness of winter cereal species in mixed cropping. Ecol. Model. 2017, 343, 123-130. [CrossRef]

6. Malaga-Tobola, U.; Tabor, S.; Kocira, S. Productivity of resources and investments at selected ecological farms. Farm Machinery And Processes Management in Sustainable Agriculture. Book Ser. Agric. Sci. Procedia 2015, 7, 158-164. [CrossRef]

7. Niemiec, M.; Komorowska, M.; Szelag-Sikora, A.; Sikora, J.; Kuboń, M.; Gródek-Szostak, Z.; Kapusta-Duch, J. Risk Assessment for Social Practices in Small Vegetable farms in Poland as a Tool for the Optimization of Quality Management Systems. Sustainability 2019, 11, 1913. [CrossRef]

8. He, Y.T.; Zhang, W.J.; Xu, M.G.; Tong, X.G.; Sun, F.X.; Wang, J.Z.; Huang, S.M.; Zhu, P.; He, X.H. Long-term combined chemical and manure fertilizations increase soil organic carbon and total nitrogen in aggregate fractions at three typical cropland soils in China. Sci. Total Environ. 2015, 532, 635-644. [CrossRef]

9. Kubon, M.; Kocira, S.; Kocira, A.; Leszczynska, D. Use of Straw as Energy Source in View of Organic Matter Balance in Family Farms. In Renewable Energy Sources: Engineering, Technology, Innovation; Springer: Cham, Switzerland, 2018; pp. 541-547. [CrossRef]

10. Eldor, I.; Paul, A. The nature and dynamics of soil organic matter: Plant inputs, microbial transformations, and organic matter stabilization. Soil Biol. Biochem. 2016, 98, 109-126. 
11. Sousa Lima, J.R.; de Moraes Silva, W.; de Medeiros, E.V.; Duda, G.P.; Metri Corrêa, M.; Martins Filho, A.P.; Clermont-Dauphin, C.; Dantas Antonino, A.C.; Hammecker, C. Effect of biochar on physicochemical properties of a sandy soil and maize growth in a greenhouse experiment. Geoderma 2018, 319, 14-23. [CrossRef]

12. Li, M.; Liu, M.; Li, Z.-P.; Jiang, C.-Y.; Wu, M. Soil N transformation and microbial community structure as affected by adding biochar to a paddy soil of subtropical China. J. Int. Agric. 2016, 15, 209-219. [CrossRef]

13. Finn, D.; Kopittke, P.M.; Dennis, P.G.; Dalal, R.C. Microbial energy and matter transformation in agricultural soils. Soil Biol. Biochem. 2017, 111, 176-192. [CrossRef]

14. Wang, Q.; Awasthi, M.K.; Ren, X.; Zhao, J.; Li, R.; Wang, Z.; Wang, M.; Chen, H.; Zhang, Z. Combining biochar, zeolite and wood vinegar for composting of pig manure: The effect on greenhouse gas emission and nitrogen conservation. Waste Manag. 2018, 74, 221-230. [CrossRef] [PubMed]

15. Thi Ngo, P.; Rumpel, C.; Janeau, J.-L.; Dang, D.-K.; Thuy Doan, T.; Jouquet, P. Mixing of biochar with organic amendments reduces carbon removal after field exposure under tropical conditions. Ecol. Eng. 2016, 91, 378-380.

16. Oliveira, F.R.; Patel, A.K.; Jaisi, D.P.; Adhikari, S.; Hui Lu, H.; Khanal, S.K. Environmental application of biochar: Current status and perspectives. Bioresour. Technol. 2018, 246, 110-122. [CrossRef] [PubMed]

17. Awasthi, M.K.; Wang, M.; Chen, H.; Wang, Q.; Zhao, J.; Ren, X.; Li, D.-S.; Awasthi, S.K.; Shen, F.; Li, R.; et al. Heterogeneity of biochar amendment to improve the carbon and nitrogen sequestration through reduce the greenhouse gases emissions during sewage sludge composting. Bioresour. Technol. 2017, 224, 428-438. [CrossRef]

18. Li, G.; Khan, S.; Ibrahim, M.; Sun, T.-R.; Tang, J.-F.; Cotner, J.B.; Xu, Y.Y. Biochars induced modification of dissolved organic matter (DOM) in soil and its impact on mobility and bioaccumulation of arsenic and cadmium. J. Hazard. Mater. 2018, 348, 100-108. [CrossRef]

19. Yang, X.; Meng, J.; Lan, Y.; Chen, W.; Yang, T.; Yuan, J.; Liu, S.; Han, J. Effects of maize stover and its biochar on soil $\mathrm{CO}_{2}$ emissions and labile organic carbon fractions in Northeast China. Agric. Ecosyst. Environ. 2017, 240, 24-31. [CrossRef]

20. Malyan, S.K.; Kumar, S.S.; Fagodiya, R.K.; Ghosh, P.; Kumar, A.; Singh, R.; Singh, L. Biochar for environmental sustainability in the energy-water-agroecosystem nexus. Renew. Sustain. Energy Rev. 2021, 149, 111379. [CrossRef]

21. Latawiec, A.E.; Koryś, A.; Koryś, K.A.; Kuboń, M.; Sadowska, U.; Gliniak, M.; Sikora, J.; Drosik, A.; Niemiec, M.; Klimek-Kopyra, A.; et al. Analysis of the economic potential through biochar use for soybean production in Poland. Agronomy 2021, 11, 2108. [CrossRef]

22. Yuan, S.; Tan, Z.; Huang, Q. Migration and transformation mechanism of nitrogen in the biomass-biochar-plant transport proces. Renew. Sustain. Energy Rev. 2018, 85, 1-13. [CrossRef]

23. Raya-Moreno, I.; Cañizares, R.; Domene, X.; Carabassa, V.; Alcañiz, J.M. Comparing current chemical methods to assess biochar organic carbon in a Mediterranean agricultural soil amended with two different biochars. Sci. Total Environ. 2017, 598, 604-618. [CrossRef]

24. Xu, X.; Zhao, Y.; Sima, J.; Zhao, L.; Mašek, O.; Cao, X. Indispensable role of biochar-inherent mineral constituents in its environmental applications: A review. Bioresour. Technol. 2017, 241, 887-899. [CrossRef]

25. Melas, G.B.; Ortiz, O.; Alacaniz, J.M. Can Biochar Protect Labile Organic Matter Against Mineralization in Soil? Pedosphere 2017, 27, 822-883. [CrossRef]

26. Plaza, C.; Giannetta, B.; Fernández, J.M.; López-de-Sá, E.G.; Polo, A.; Gascó, G.; Méndez, A.; Zaccone, C. Response of different soil organic matter pools to biochar and organic fertilizers. Agric. Ecosyst. Environ. 2016, 225, 150-159. [CrossRef]

27. Awad, Y.M.; Lee, S.S.; Kim, K.-H.; OK, Y.S.; Kuzyakov, Y. Carbon and nitrogen mineralization and enzyme activities in soil aggregate-size classes: Effects of biochar, oyster shells, and polymers. Chemosphere 2018, 198, 40-48. [CrossRef]

28. Xu, X.; Kan, Y.; Zhao, L.; Cao, X. Chemical transformation of $\mathrm{CO}_{2}$ during its capture by waste biomass derived biochars. Environ Pollut. 2016, 213, 533-540. [CrossRef]

29. Oni, B.A.; Oziegbe, O.; Olawwole, O. Significance of biochor application to the environment and economy. Ann. Agric. Sci. 2019, 64, 222-236. [CrossRef]

30. Pietrzykowski, M.; Wos, B.; Tylek, P.; Kwasniewski, D.; Juliszewski, T.; Walczyk, J.; Likus-Cieslik, J.; Ochal, W.; Tabor, S. Carbon sink potential and allocation in above- and below-ground biomass in willow coppice. J. For. Res. 2021, 32, 349-354. [CrossRef]

31. Kowalczyk, Z.; Kwaśniewski, D. Environmental impact of the cultivation of energy willow in Poland. Sci. Rep. 2021, 11, 1. [CrossRef]

32. Maucieri, C.; Zhang, Y.; McDaniel, M.D.; Borin, M.; Adams, M.A. Short-term effects of biochar and salinity on soil greenhouse gas emissions from a semi-arid Australian soil after re-wetting. Geoderma 2017, 307, 267-276. [CrossRef]

33. Smebye, A.B.; Sparrevik, M.; Schmidt, H.P.; Cornelissen, G. Life-cycle assessment of biochar production systems in tropical rural areas: Comparing flame curtain kilns to other production methods. Biomass Bioenergy 2017, 101, 35-43. [CrossRef]

34. Kubon, M.; Latawiec, A.E.; Scarano, F.R.; Drosik, A.; Strassburg, B.B.N.; Grzebieniowski, W.; Bastos, J.G. Searching for solutions to the conflict over Europe's oldest forest. Conserv. Biol. 2019, 33, 476-479. [CrossRef]

35. Klimek-Kopyra, A.; Sadowska, U.; Kubon, M.; Gliniak, M.; Sikora, J. Sunflower Husk Biochar as a Key Agrotechnical Factor Enhancing Sustainable Soybean Production. Agriculture 2021, 11, 305. [CrossRef]

36. Montgomery, D.C. Design and Analysis of Experiments, 3rd ed.; John Wiley \& Sons, Inc.: New York, NY, USA, 1991. 
37. Nemecek, T.; Bengoa, X.; Lansche, J.; Mouron, P.; Rossi, V.; Humbert, S. Methodological Guidelines for the Life Cycle Inventory of Agricultural Products. Version 2.0, July World Food LCA Database (WFLDB); Quantis and Agroscope: Lausanne, Switzerland; Zurich, Switzerland, 2014.

38. Devapriya, P.; Ferrell, W.; Geismar, N. Integrated production and distribution scheduling with a perishable product. Eur. J. Oper. Res. 2017, 259, 906-916. [CrossRef]

39. Publications Office of the European Union. International Reference Life Cycle Data System (ILCD) Handbook-General Guide for Life Cycle Assessment_-Provisions and Action Steps; Publications Office of the European Union: Luxemboug, 2010.

40. Kool, A.; Marinussen, M.; Blonk, H. LCI Data for the Calculation Tool Feed Print for Greenhouse Gas Emissions of Feed Production and Utilization: GHG Emissions of N, P, and K Fertilizer Production. Research Station ART. 2012. Available online: Blonkconsultants.nl (accessed on 1 January 2021).

41. Nemecek, I.; Schnetzer, J. Methods of Assessment of Direct Field Emissions for LCIs of Agricultural Production Systems Data v3.0; Agroscope Reckenholz-Tänikon Research Station ART: Zurich, Switserland, 2012.

42. Intergovernmental Panel on Climate Change. IPCC Guidelines for National Greenhouse Gas Inventories, Vol. 4: Agriculture, Forestry and Other Land Use; Intergovernmental Panel on Climate Change: Geneva, Switzerland, 2006.

43. Novoa, R.S.A.; Tejeda, H.R. Evaluation of the $\mathrm{N}_{2} \mathrm{O}$ emissions from $\mathrm{N}$ in plant residues as affected by environmental and management factors. Nutr. Cycl. Agroecosyst. 2006, 75, 29-46. [CrossRef]

44. Forster, P. Changes in Atmospheric Constituents and Radiative Forcing. In Climate Change 2007: The Physical Science Basis. Contribution of Working Group I to the Fourth Assessment Report of the Intergovernmental Panel on Climate Change; Cambridge University Press: Cambridge, UK, 2007; p. 212.

45. Wójcicki, Z. Methodology of examining energy consumption of agricultural production. Probl. Inż. Rol. 2015, $23,17-29$.

46. EPA United States Environmental Protection Agency. Greenhouse Gas Inventory Guidance Direct Emissions from Mobile Combustion Sources; EPA United States Environmental Protection Agency: Washington, DC, USA, 2016; p. 27.

47. Torrez Irigoyen, R.M.; Giner, S.A. Drying-toasting of presoaked soybean in fluidised bed. Modeling, validation and simulation of operational variants for reducing energy consumption. J. Food Eng. 2016, 171, 78-86. [CrossRef]

48. FAO. Global Database of GHG Emissionsrelated to Feedcrops: Methodology. Version 1. Livestock Environmental Assessment and Performance Partnership; FAO: Rome, Italy, 2017.

49. Llorach-Massana, P.; Lopez-Capel, E.; Peña, J.; Rieradevalla, J.; Montero, J.I.; Puy, N. Technical feasibility and carbon footprint of biochar co-production with tomato plant residue. Waste Manag. 2017, 67, 121-130. [CrossRef] [PubMed]

50. Lehmann, L.; Abiven, S.; Kleber, M.; Pan, G.; Singh, B.P.; Sohi, S.; Zimmerman, A. Persistence of biochar in soil. In Biochar for Environmental Management_Science, Technology and Implementation, 2nd ed.; Lehmann, J., Joseph, S., Eds.; Routledge: Abingdon, UK, 2015; pp. 235-283.

51. FAO. Status of the World's Soil Resources Main Report Prepared by Intergovernmental Technical Panel on Soils (ITPS); FAO: Rome, Italy, 2015.

52. Niemiec, M.; Chowaniak, M.; Sikora, J.; Szelag-Sikora, A.; Grodek-Szostak, Z.; Komorowska, M. Selected properties of soils for long-term use in organic farming. Sustainability 2020, 12, 2509. [CrossRef]

53. Gong, H.; Lia, Y.; Li, S. Effects of the interaction between biochar and nutrients on soil organic carbon sequestration in soda saline-alkali grassland: A review. Glob. Ecol. Conserv. 2021, 26, 01449. [CrossRef]

54. De Figueiredo, C.C.; Moura Chagas, J.K.; da Silva, J.; Paz-Ferreiro, J. Short-term effects of a sewage sludge biochar amendment on total and available heavy metal content of a tropical soil. Geoderma 2019, 344, 31-39. [CrossRef]

55. Odinga, E.S.; Gudda, F.O.; Waigi, M.G.; Wang, Y.; Gao, Y. Occurrence, formation and environmental fate of polycyclic aromatic hydrocarbons in biochars. Fundam. Res. 2021, 1, 296-305. [CrossRef]

56. Floe, O.T.; Alatise, M.O.; Ajayi, A.E.; Ewulo, B.S. Effects of biochar and inorganic fertiliser applications on growth, yield and water use efficiency of maize under deficit irrigation. Agric. Water Manag. 2019, 217, 165-178. [CrossRef]

57. Ndor, E.; Dauda, S.N.; Azagaku, E.D. Response of Maize Varieties (Zea mays) to Biochar. Amended Soil in Lafia, Nigeria. Am. J. Exp. Agric. 2015, 5, 525-531. [CrossRef]

58. Krause, H.-M.; Hüppi, R.; Leifeld, J.; El-Hadidi, M.; Harter, J.; Kappler, A.; Hartmann, M.; Behrens, S.; Mäder, P.; Gattinger, A. Biochar affects community composition of nitrous oxide reducers in a field experiment. Soil Biol. Biochem. 2018, 119, 143-151. [CrossRef]

59. Wang, X.; Song, D.; Liang, G.; Zhang, Q.; Ali, C.; Zhou, W. Maize biochar addition rate influences soil enzyme activity and microbial community composition in a fluvo-aquic soil. Appl. Soil Ecol. 2015, 96, 265-272. [CrossRef]

60. Sánchez-García, M.; Sánchez-Monedero, M.A.; Cayuela, M.L. $\mathrm{N}_{2} \mathrm{O}$ emissions during Brassica oleracea cultivation: Interaction of biochar with mineral and organic fertilization. Eur. J. Agric. 2020, 115, 126021. [CrossRef]

61. Zortea, R.B.; Maciel, V.G.; Passuello, A. Sustainability assessment of soybean production in Southern Brazil: A life cycle approach. Sustain. Prod. Consum. 2018, 13, 102-112. [CrossRef]

62. Rajaeifar, M.A.; Ghobadian, B.; Safa, M.; Heidari, M.D. Energy life-cycle assessment and $\mathrm{CO}_{2}$ emissions analysis of soybean-based biodiesel: A case study. J. Clean. Prod. 2014, 66, 233-241. [CrossRef]

63. Wang, L.; Yang, K.; Gao, C.; Zhu, L. Effect and mechanism of biochar on $\mathrm{CO}_{2}$ and $\mathrm{N}_{2} \mathrm{O}$ emissions under different nitrogen fertilization gradient from an acidic soil. Sci. Total Environ. 2020, 747, 141265. [CrossRef]

64. Niemiec, M.; Cupiał, M.; Szelag-Sikora, A. Evaluation of the Efficiency of Celeriac Fertilization with the Use of Slow-acting Fertilizers. Agric. Agric. Sci. Procedia. 2015, 7, 177-183. [CrossRef] 
65. Chowaniak, M.; Rashidov, N.; Niemiec, M.; Gambuś, F.; Lepiarczyk, A. The Impact of Training Systems on Productivity and GHG Emissions from Grapevines in the Sughd Region in Northern Tajikistan. Agronomy 2020, 10, 818. [CrossRef]

66. Sikora, J.; Niemiec, M.; Szelag-Sikora, A.; Gródek-Szostak, Z.; Kuboń, M.; Komorowska, M. The Impact of a Controlled-Release Fertilizer on Greenhouse Gas Emissions and the Efficiency of the Production of Chinese Cabbage. Energies 2020, $13,2063$. [CrossRef]

67. Costantini, M.; Bacenetti, J. Soybean and maize cultivation in South America: Environmental comparison of different cropping systems. Clean. Environ. Syst. 2021, 2, 100017. [CrossRef]

68. Liang, L.; Lal, R.; Ridoutt, B.G.; Du, Z.L.; Wang, D.P.; Wang, L.Y.; Wu, W.L.; Zhao, G.S. Life cycle assessment of China's agroecosystems. Ecol. Indic. 2018, 88, 341-350. [CrossRef]

69. Sikora, J.; Niemiec, M.; Tabak, M.; Gródek-Szostak, Z.; Szelag-Sikora, A.; Kuboń, M.; Komorowska, M. Assessment of the efficiency of nitrogen slow-release fertilizers in integrated production of carrot depending on fertilization strategy. Sustainability 2020, 12, 1982. [CrossRef]

70. Gródek-Szostak, Z.; Luc, M.; Szelag-Sikora, A.; Sikora, J.; Niemiec, M.; Ochoa Siguencia, L.; Velinov, E. Promotion of RES in a Technology Transfer Network. Case Study of the Enterprise Europe Network. Energies 2020, 13, 3445. [CrossRef]

71. Majumder, S.; Neogi, S.; Dutta, T.; Powel, M.A.; Banik, P. The impact of biochar on soil carbon sequestration: Meta-analytical approach to evaluating environmental and economic advantages. J. Environ. Manag. 2019, 250, 109466. [CrossRef]

72. Owsianiak, M.; Lindhjem, H.; Cornelissen, G.; Hale, S.E.; Sørmo, E.; Sparrevik, M. Environmental and economic impacts of biochar production and agricultural use in six developing and middle-income countries. Sci. Total Environ. 2021, 755, 142455. [CrossRef] 